\title{
Kışlık ve Yazlık Yetiştirilen Nohut (Cicer arietinum L.)'ta Ekim Zamanlarına Göre Bitkide Tane Verimi ile Bazı Bitkisel Özellikler Arasındaki İlişkilerin İncelenmesi
}

\author{
*Oral DÜZDEMIR \\ Çankırı Karatekin Üniversitesi, Fen Fakültesi, Biyoloji Bölümü, Çankırı \\ Sorumlu yazar e-posta (Corresponding author e-mail): orald@karatekin.edu.tr
}

Öz

Bu çalışmada amaç, nohutta bitkide tane verimi ile diğer özellikler arasındaki ilişkileri belirleyerek kışlık ve yazlık ekime uygun bitki tipini ortaya koyabilmektir. Denemeler 1999-2001 yıllarında Tokat şartlarında, Tesadüf Blokları Bölünmüş Parseller Deneme deseninde 3 tekerrürlü olarak düzenlenmiştir. Ana parsellere ekim zamanları (kışlık ve yazlık), alt parsellere çeşitler yerleştirilmiştir. Araştırmada bitki boyu, ilk bakla yüksekliği, bitkide bakla sayısı, bitkide tane sayısı, bitkide toplam verim, bitkide tane verimi, bitkide hasat indeksi ve 1000 tane ağırlığı özellikleri ele alınmıştır. Ekim zamanlarına göre bitkide tane verimi ile diğer bitkisel özellikler arasındaki ilişkiler korelasyon ve path analizi yöntemleri kullanılarak belirlenmiştir.

Anahtar Kelimeler: Nohut, verim, korelasyon analizi, path analizi

\section{Determining the Relationships between Seed Yield per Plant and Some Plant Characteristics According to Sowing Dates in Chickpea (Cicer arietinum L.) Grown in Winter and Summer}

\begin{abstract}
The aim of this study is to present favourable plant types for winter and summer sowing by determining the relationships between plant seed yields and other characteristics. Field trials were arranged randomized blocks in split plot design with three replications in Tokat conditions in the year 1999-2001. Sowing dates (winter and summer) were located in main plots, varieties in sub-plots. In the study, plant height, first pod height, number of pod per plant, number of seed per plant, total biological yield per plant, seed yield per plant, harvest index per plant and 1000-seed weight were examined. Relationships between seed yield per plant and other characteristics were determined using correlation and path analysis methods according to sowing dates.
\end{abstract}

Keywords: Chickpea, yield, correlation analysis, path analysis

\section{Giriş}

$\mathrm{N}$ ohudun gen merkezi olarak içinde Türkiye'nin de yer aldığı Doğu Akdeniz'dir (Akçin 1988). Türkiye'de 2014 yılı için nohut ekim alanı 388.517.7 ha, üretim miktarı 450.000 tondur (TUIK 2015). Bu rakamlar ile nohut Türkiye'de en çok yetiştirilen yemeklik tane baklagil cinsidir.

Taneleri yüksek oranda protein (\%15-32) ve karbonhidrat (\%50-74) içeren nohut, insanların diyetlerinde önemli yer tutar (Smithson et al. 1985). Kurağa ve düşük sıcaklığa nispeten dayanıkılığı, toprak açısından fazla seçici olmaması, Rhizobium bakterileriyle havanın azotunu toprağa bağlaması, onun tarımsal açıdan önemli birkaç özelliğidir. Kolay yetiştirilmesi, gelişme döneminin kısalığı, onu tahıllarla ekim nöbetine girebilen birkaç bitkiden biri yapar (Sepetoğlu 1994).

Soğuk ve yanıklık hastalığı Akdeniz iklimine sahip alanlarda, nohudun kışlık ekimini sınırlamaktadır. Üreticiler bunların etkilerinden kaçmak için ekimi geciktirirler (Saxena 1985; Özdemir and Karadavut 2003). Kıştan kalan rutubet geciken ekimlerde verimi belirleyici faktör olmaktadır. Türkiye'de, nohut Şubat ayı ortasından Mayıs'a kadar ekilir (Sepetoğlu 1994).

Bitkilerde verim üzerinde bitkisel özelliklerin ortak etkisi söz konusuyken aynı zamanda çevresel faktörlerde değişen oranlarda etkiye sahiptir. Nohutta tane verimi genetik yapı, 
yetişme dönemi, coğrafik yapı ve yetiştiricilik uygulamaları gibi faktörlerden etkilenir (Tawaha et al. 2005).

Nohutta verimle bitkisel özellikler arası ilişkilerin belirlendiği bazı çalışmalarda; bitkide bakla, dolu bakla, tane, birinci ve ikinci dal sayıları, 100 tane ağırlığı, bitkide tane verimi, biyolojik verim ve hasat indeksinin olumlu etkileri saptanmıştır (Eser ve ark. 1989; Akdağ ve Şehirali 1992; Erman ve ark. 1997; Güler ve ark. 2001; Sağır ve ark. 2004; Çiftçi ve ark. 2004, Düzdemir ve ark. 2009)

Yücel et al. (2006) nohutta tane sayısıyla, dolu bakla sayısının bitkide tane verimi üzerinde en yüksek doğrudan ve olumlu etkiye sahip olduklarını, kabuli tip kışlık nohut geliştiirirken de bu iki özelliğin dikkate alınmasının uygun olacağını ifade etmişlerdir.

Son yıllarda, soğuğa ve yanıklığa dayanıkı yeni nohut çeşitleri geliştirmek, Islah çalışmalarının önemli amaçlarındandır (Toker ve Çağırgan 1996; Singh 1997). Araştırmalarda yanıklığa dayanıklı çeşitlerle yapılan kışlık ekimlerde yazlığa göre daha çok verim elde edilmiştir (Singh et al. 1992, 1997; Toker ve Çağırgan 1996; Akdağ 2001; Iliadis 2001). Nohutta adaptasyon sınırları dar olduğu için aynı çeşitler ile farklı çevrelerde değişik sonuçlar alınabilmektedir (Özdemir and Engin 1994; Düzdemir ve Akdağ 2007). Singh and Bejiga (1990) yazlık ve kışlık çevre koşulları için çeşit ıslahının ayrı ayrı yapılmasını önermektedirler. Nohutta belirli çevrelere uyumlu çeşitler geliştirilirken, morfolojik karakterler için özel analizler yapılması tavsiye edilmektedir (Al-Rifaee et al. 2007).

Bitkisel karakterlerle verim arasındaki ilişkiler incelenirken ikili doğrusal ilişkilerin ele alındığı korelasyon katsayısı ele alınmakta fakat; bu katsayı ile bağımsız değişkenler arasındaki ikili ilişkilerle, aralarındaki doğrusal ilişkilerin derecesi belirlenmektedir. Oysa bitkisel karakterlerin birbirleri üzerlerinden dolaylı etkileri de mevcuttur. Bu etkilerin detaylı bir şekilde ele alınabilmesi için path analizine başvurulmakta, bu yöntemde korelasyon katsayısındaki dorudan etki ile dolaylı etkilerin oranları belirlenerek, bitkisel karakterler arasındaki ilişkiler daha detaylı bir şekilde yorumlanabilmektedir (Çiftçi ve ark. 2004, Yücel ve ark. 2006).

$\mathrm{Bu}$ çalışmanın amacı nohutta bitkide tane verimi ile diğer özellikler arasındaki ilişkiler ile kışlık ve yazlık ekime uygun, yüksek verimli bitki tipini ortaya koyabilmektir.

\section{Materyal ve Yöntem}

Tokat şartlarında 1999-2001 yıllarında yürütülen bu çalışmada kullanılan çeşitlere ait bazı bilgiler Çizelge 1'de verilmiştir.

Araştırma yıllarında uzun yıllara göre (ortalama sıcaklık: $11.1^{\circ} \mathrm{C}$, toplam yağış: 445.7 $\mathrm{mm}$ ve nispi nem: \%60.1) ortalama sıcaklık $\left(9.4^{\circ} \mathrm{C}\right)$ düşük, toplam yağış $(473.1 \mathrm{~mm})$ ve nispi nem (\%75.0) daha yüksek olmuştur. Deneme alanları killi-tınlı, tuzsuz, hafif alkali, organik madde ve elverişli fosfor açısından fakir, potasyum açısından zengindir.

Tarla denemeleri Tesadüf Blokları Bölünmüş Parseller Deneme deseninde 3 tekerrürlü olarak düzenlenmiş, ana parsellere ekim zamanları alt parsellere de çeşitler yerleştirilmiştir. Ekimler kışlık olarak 09-27 Kasım 1999-2000; yazlıklar da 24-19 Mart 2000-2001'de yapılmıştır. Çeşitler $5 \mathrm{~m}$ x 0.40 $\mathrm{m} \times 2$ sıra (toplam $4 \mathrm{~m}^{2}$ ) parsellerde $10 \mathrm{~cm}$ sıra üzeri mesafeyle elle ekilmiş, aralarında boşluk bırakılmamıştır. Blok baş ve sonundaki çeşitlerde kenar tesiri amaçlı dış tarafa birer sıra daha ekilmiştir. Ekimden önce her bir parsele $2.7 \mathrm{~kg} \mathrm{~N} / \mathrm{da}$ ve $6.9 \mathrm{~kg} \mathrm{P}_{2} \mathrm{O}_{5} / \mathrm{da}$ hesabı ile diamonyum fosfat gübresi verilmiştir. Çalışmada, bitki boyu (cm), ilk bakla yüksekliği $(\mathrm{cm})$, bitkide bakla sayısı (adet), bitkide tane sayısı (adet), 1000 tane ağırlığı (g), bitkide toplam verim ( $\mathrm{g} / \mathrm{bitki}$ ), bitkide tane verimi (g/bitki) ve hasat indeksi (\%) özellikleri Tosun ve Eser (1975) bildirdiklerine göre belirlenmiştir.

Çizelge 1. Çalışmada kullanılan genotiplere ait bazı bilgiler

Table 1. Informations about genotypes used in this study

\begin{tabular}{llccc}
\hline Çeşit Adı & Özelliği & Tane Tipi & Bintane Ağ. $(\mathrm{g})$ & Antraknoza day. \\
\hline Akçin-91 & Tescilli Çeşit & Koçbaşı & $400-430$ & Toleranslı \\
Aziziye-94 & Tescilli Çeşit & Koçbaşı & 500 & Dayanıklı \\
Er-99 & Tescilli Çeşit & Koçbaşı & $470-480$ & Dayanıklı \\
Uzunlu-99 & Tescilli Çeşit & Koçbaşı & $500-510$ & Toleranslı \\
Küsmen-99 & Tescilli Çeşit & Koçbaşı & $500-510$ & Dayanıklı \\
AK-71114 & Üretim İzinli & Kuşbaşı & --- & Toleranslı \\
\hline
\end{tabular}


Elde edilen sonuçlar yıllara göre TARIST paket istatistik bilgisayar programında varyans ve korelasyon analizine tabi tutulurken, path analizi ise yıllar üzerinden birleştirilmiş değerlerden yapılmıştır. Önemlilik gösteren ortalamalara LSD testi uygulanmıştır (Yurtsever 1984).

\section{Bulgular ve Tartışma}

Tokat ekolojik koşullarında kışlık ve yazlık olarak iki yıl yetiştirilen 6 nohut çeşidinde incelenen özelliklere ait korelasyon katsayıları Çizelge 2'de verilmiştir.

Çizelge 2 incelendiğinde kışlık ekimde bitkide tane verimi ile en yüksek ve olumlu ikili ilişki bitkide tane sayısı $\left(0.648^{* *}\right)$ arasında belirlenirken onu $0.541^{* *}$ değeri ile bitkide bakla sayısı takip etmiştir. Kışıık ekimde bitkide tane verimi ile ele alınan yukarıdaki karakterler dışında kalan diğer özellikler arasında istatistiksel anlamda önemli ilişkiler olmadığı saptanmıştır. Yazlık ekimde bitkide tane verimi ile diğer özellikler arasındaki ikili ilişkiler incelendiğinde en yüksek ve olumlu ilişkinin bitkide toplam verim $\left(0.823^{* *}\right)$ arasında olduğu görülmüştür. Bitkide toplam verim özelliğini $0.724^{* *}$ ve $0.684^{* *}$ değerleri ile sırasıyla bitkide bakla ve tane sayısı özellikleri takip etmiştir. Yazlık ekimde de bu üç özellik dışında kalan diğer özellikler ile bitkide tane verimi arasında istatistiksel olarak önemli herhangi bir ilişki bulunmadığı belirlenmiştir.
Yine Çizelge 2'deki diğer bitkisel özellikler arasındaki ikili ilişkiler gözden geçirildiğinde, bitki boyunun hem kışlık hem de yazlık ekimde sadece ilk bakla yüksekliğiyle olumlu ve çok önemli ilişkiler sergilediği görülmüştür. Illk bakla yüksekliği ise sadece kışılı ekimde bitkide bakla sayısı $\left(0.348^{*}\right)$, bitkide tane sayısı $\left(-0.367^{*}\right)$ ve bitkide toplam verimle $\left(-0.348^{*}\right)$ olumsuz ve önemli, 1000 tane ağırlığıyla da $\left(0.395^{*}\right)$ olumlu ve önemli ilişkiler ortaya koymuştur. Bitkide bakla sayısı ile bitkide tane sayısı (K:0.859**, Y:0.437**) ve bitkide toplam verim (K:0.781**, Y:0.699**) arasında her iki ekim zamanında da olumlu ve çok önemli ilişkiler bulunduğu tespit edilmiştir. Bitkide tane sayısı da yine her iki ekim zamanında bitkide toplam verim arasında olumlu ve önemli ilişkiler (K: $0.357^{*}$, Y: $0.570^{* *}$ ) belirlenmiştir. Bitkide hasat indeksi ile 1000 tane ağılığı arasında yazlık ekimde olumlu ve çok önemli ilişkiler olduğu da Çizelge 2'de görülmektedir.

Verim ile bitkisel karakterler arasındaki ilişkileri ortaya sergileyen korelasyon katsayı ile bağımsız değişkenler arasındaki ikili ilişkiler ve aralarındaki doğrusal ilişkilerin derecesi belirlenmektedir.

Oysa bitkisel karakterlerin birbirleri üzerlerinden dolaylı etkileri de mevcuttur. Bu etkilerin detaylı bir şekilde ele alınabilmesi için path analizine başvurularak doğrudan ve dolaylı

Çizelge 2. Bitki tane verimiyle diğer bitkisel özellikler arasındaki ilişkilere ait korelasyon katsayıları

Table 2. Correlation coefficients between seed yield per plant and other traits

\begin{tabular}{|c|c|c|c|c|c|c|c|c|c|}
\hline \multicolumn{2}{|c|}{ Özellikler } & BTAV & BB & İBY & BBS & BTS & BTOV & $\mathrm{BHI}$ & B TA \\
\hline & $\mathrm{K}$ & 1.000 & -0.015 & -0.257 & $0.541^{* *}$ & $0.648^{* \star}$ & 0.260 & 0.085 & -0.043 \\
\hline \multirow{2}{*}{ BTAV } & Y & 1.000 & 0.051 & -0.132 & $0.724^{\star *}$ & $0.684^{\star \star}$ & $0.823^{* *}$ & 0.214 & 0.176 \\
\hline & $\mathrm{K}$ & & 1.000 & $0.784^{\star *}$ & -0.109 & -0.082 & -0.269 & -0.010 & 0.315 \\
\hline BB & $Y$ & & 1.000 & $0.877^{* *}$ & -0.099 & -0.054 & 0.091 & 0.033 & -0.077 \\
\hline \multirow{2}{*}{ IBY } & K & & & 1.000 & $-0.348^{*}$ & $-0.367^{*}$ & $-0.348^{*}$ & -0.196 & $0.395^{*}$ \\
\hline & $\mathrm{Y}$ & & & 1.000 & -0.237 & -0.131 & -0.068 & 0.048 & -0.136 \\
\hline \multirow{2}{*}{ BBS } & K & & & & 1.000 & $0.859^{* *}$ & $0.437^{* *}$ & 0.074 & -0.124 \\
\hline & $Y$ & & & & 1.000 & $0.781^{* *}$ & 0.699 ** & -0.026 & -0.05 \\
\hline \multirow{2}{*}{ BTS } & K & & & & & 1.000 & $0.357^{*}$ & 0.097 & -0.112 \\
\hline & Y & & & & & 1.000 & $0.570^{* *}$ & -0.072 & -0.015 \\
\hline \multirow{2}{*}{ BTOV } & K & & & & & & 1.000 & -0.032 & 0.036 \\
\hline & $Y$ & & & & & & 1.000 & -0.039 & 0.038 \\
\hline \multirow{2}{*}{$\mathrm{BHI}$} & K & & & & & & & 1.000 & 0.083 \\
\hline & $Y$ & & & & & & & 1.000 & $0.384^{* *}$ \\
\hline \multirow{2}{*}{ BTA } & K & & & & & & & & 1.000 \\
\hline & $\mathrm{Y}$ & & & & & & & & 1.000 \\
\hline
\end{tabular}

K, Y, BTAV, BB, İBY, BBS, BTS, BTOV, BHI, BTA = Sırasıyla, kışlık ekim, yazlık ekim, bitkide tane verimi, bitki boyu, ilk bakla yüksekliği, bitkide bakla sayısı, bitkide tane sayısı, bitkide toplam verim, bitkide hasat indeksi, 1000 tane ağırlığı.

*, ** Sırasıyla istatistiksel olarak 0.05 ve 0.01 düzeyinde önemli.

K: Sowing date - winter, Y: Sowing date - yield, BTAV: Seed yield per plant, BB: Plant height, IBY: First pod height, BBS: Number of pods per plant, BTS: number of seeds per plant, BTOV: Total biological yield per plant, BHI: harvest index per plant, BTA: 1000 seed weight

*, ** Significantly different from each other at 0.05 and 0.01 levels, respectively. 
etkilerin oranları belirlenerek, bitkisel karakterler arasındaki ilişkiler daha detaylı bir şekilde yorumlanabilmektedir (Çiftçi ve ark. 2004; Yücel ve ark. 2006).

Nohutta tane verimi oluşumunda bitkisel özelliklerin etki oranlarını belirlemek için yapılan path analizi sonuçları Çizelge 3'de verilmiştir.

Çizelge 3 ele alındığında ekim zamanlarına göre bitkide tane veriminin oluşumu üzerinde doğrudan, yüksek etkilere sahip olan bitkisel karakterlerin değiştiği görülecektir. Aynı zamanda doğrusal etkiler yanında dolaylı etkiler de benzer durum söz konusudur.

Kışlık ekimde tane verimi oluşumunda bitkisel karakterlerin doğrudan etkileri ele alındığında, en yüksek doğrudan etkinin \%85.2062 ile bitkide tane sayısı özelliğinin sahip olduğu görülecektir. Bu özelliği \%43.9464 ile bitki boyu izlemiştir. Ancak bitki boyunun negatif katsayıya sahip olması nedeniyle bitki boyunun etkisi olumsuz yönde olmaktadır. Kışlık ekimde bitkide tane sayısı doğrudan şekilde tane verimi oluşumunu etkilerken, dolaylı ilişkiler incelendiğinde farklı bitkisel karakterlerin dolaylı etkilerinin gerçekleşmesinde de önemli rol oynamıştır. Örneğin bitkide bakla sayısı özelliğinin tane verimi oluşumu üzerine bitkide tane sayısı üzerinden dolaylı etkisi \%81.5230 olurken yine bitkide toplam verim $\% 66.7744$, bitkide hasat indeksinin \%54.0642 ve 1000 tane ağırlığının da \%42.1615 oranında olduğu görülmüştür. Bitki boyu ve ilk bakla yüksekliği özeliklerinde de bitkide tane sayısı üzerinden yüksek sayılabilecek dolaylı etkilere sahip olsalar da bu etkiler negatif katsayıları nedeniyle olumsuz yönde gerçekleşmiştir. Kışlık ekimde bitkide tane sayısı ve bitki boyu dışına kalan diğer bitkisel özelliklerin doğrusal etkileri düşük oranlarda gerçekleşirken tane oluşumu üzerine etkileri daha çok dolaylı etkilerden olduğu yine Çizelge 3'den görülmektedir.

Yazlık ekimde tane verimi oluşumunda bitkisel karakterlerin doğrudan etkileri ele alındığında, en yüksek doğrudan etkinin \%74.0437 ile bitkide hasat indeksi özelliği sahipken onu \%68.9731 oranı ile bitkide toplam verim takip etmiştir. Bitki boyu ve bitkide tane sayısı karakterleri de yazlık ekimde tane oluşumu üzerinde sırasıyla $\% 43.5784$ ve \%42.6030 oranında doğrudan olumlu etkilere sahipken ilk bakla yüksekliği de yine \%44.4543 oranında bir etkiye sahip olmasına rağmen negatif katsayısı nedeniyle bu etki daha olumsuz yönlü olmaktadır. Dolaylı ilişkiler incelendiğinde de yine bitkide tane sayısı, bitki de toplam verim ve bitkide hasat indeksi özellikleri üzerinden bitki boyu, bitkide bakla sayısı, bitkide tane sayısı, bitkide toplam verim ve 1000 tane ağırlığının olumlu fakat dolaylı şekilde etkileri, ilk bakla yüksekliğinin ise olumsuz yönde etkileri olduğu görülecektir (Çizelge 3).

Çalışmamızda elde ettiğimiz bulgular gözden geçirildiğinde kısaca;

1) Korelasyon katsayılarının yer aldığı Çizelge 2 incelendiğinde kışlık ekimde bitkide tane verimi ile en yüksek ve olumlu ikili ilişki bitkide tane sayısı $\left(0.648^{* *}\right)$ arasında belirlenirken onu $0.541^{* *}$ değeri ile bitkide bakla sayısı takip etmiştir. Yazlık ekimde de bitkide tane verimi ile en yüksek ve olumlu ilişkinin bitkide toplam verim $\left(0.823^{* *}\right)$ arasında olduğu görülmüştür.

2) Path katsayısı ve oranlarının yer aldığı Çizelge 3'e bakıldığında değişen ekim zamanına göre verimin oluşumunda doğrudan olumlu, yüksek etkiye sahip karakterlerin değiştiği görülmüştür.

Bulgularımız, Eser ve ark. (1989), Akdağ ve Şehirali (1992), Erman ve ark. (1997), Güler ve ark. (2001), Sağır ve ark. (2004), Çiftçi ve ark. (2004) ve Düzdemir ve ark., (2009)'nın bildirişlerini destekler niteliktedir. Çalışmada elde edilen korelasyon katsayıları incelendiğinde kışlık ve yazlık ekimlerde bitkide bakla sayısı, bitkide tane sayısı ve bitkide toplam verimin tane verimi ile aralarında çok önemli ve olumlu ilişkiler olduğu saptanmıştır.

Nohutta adaptasyon sınırları dar olduğu için aynı çeşitler ile farklı çevrelerde değişik sonuçlar alınabilmektedir (Özdemir ve Engin 1994; Düzdemir ve Akdağ 2007). Singh ve Bejiga (1990) yazlık ve kışlık çevre koşulları için çeşit ıslahının ayrı ayrı yapılmasını önermektedirler. Nohutta belirli çevrelere uyumlu çeşitler geliştirilirken, morfolojik karakterler için özel analizler yapılması tavsiye edilmektedir (Al-Rifaee et al. 2007).

Çalışmamızda yaptığımız path analizi de bu bildirişleri doğrular nitelikte olduğu görülmüştür. Kışlık ve yazlık olarak değişen ekim zamanına bağlı olarak bitkide tane verimi özelliğinin oluşumu üzerinde yüksek ve olumlu doğrudan etkilere sahip olan bitkisel karakterlerin değiştiği bulunmuştur. Yücel ve ark. (2006), nohutta tane sayısıyla, dolu bakla sayısının bitkide tane 
Düzdemir "Kışlık ve Yazlık Yetiştirilen Nohut (Cicer arietinum L.)’ta Ekim Zamanlarına Göre Bitkide Tane Verimi ile Bazı Bitkisel Özellikler Arasındaki Ilişkilerin Incelenmesi”

Çizelge 3. Bitki tane verimi ile diğer bitkisel özellikler arasındaki path katsayı ve oranları Table 3. IPath coefficients and percentages between seed yield per plant and other traits

\begin{tabular}{|c|c|c|c|c|}
\hline \multirow[b]{3}{*}{ Bitki Boyu } & \multicolumn{2}{|c|}{ Kışlık Ekim } & \multicolumn{2}{|c|}{ Yazlık Ekim } \\
\hline & Path Katsayısı & $\%$ & Path Katsayısı & $\%$ \\
\hline & -0.1160 & 43.9464 & 0.2397 & 43.5784 \\
\hline İlk bakla yüksekliği & -0.0614 & 23.2603 & -0.2243 & 40.7773 \\
\hline Bitkide bakla sayısı & 0.0088 & 3.3326 & -0.0042 & 0.7563 \\
\hline Bitkide tane sayısı & -0.0591 & 22.4120 & -0.0172 & 3.1259 \\
\hline Bitkide toplam verim & -0.0088 & 3.3352 & 0.0527 & 9.5855 \\
\hline Hasat İndeksi & -0.0003 & 0.1222 & 0.0081 & 1.4755 \\
\hline 1000 tane ağırlığı & 0.0095 & 3.5913 & -0.0039 & 0.7011 \\
\hline İlk bakla yüksekliği & 0.0783 & 15.8698 & -0.2558 & 44.4543 \\
\hline Bitki boyu & -0.0909 & 18.4311 & 0.2102 & 36.5406 \\
\hline Bitkide bakla sayısı & 0.0281 & 5.6966 & -0.0100 & 1.7372 \\
\hline Bitkide tane sayısı & -0.2662 & 53.9479 & -0.0415 & 7.2151 \\
\hline Bitkide toplam verim & -0.0114 & 2.3073 & -0.0393 & 6.8376 \\
\hline Hasat İndeksi & -0.0066 & 1.3328 & 0.0116 & 2.0242 \\
\hline 1000 tane ağırlığı & 0.0119 & 2.4145 & -0.0069 & 1.1909 \\
\hline Bitkide bakla sayısı & -0.0808 & 10.5720 & 0.0422 & 5.3433 \\
\hline Bitki boyu & 0.0126 & 1.6527 & -0.0237 & 2.9976 \\
\hline İlk bakla yüksekliği & -0.0272 & 3.5652 & 0.0606 & 7.6836 \\
\hline Bitkide tane sayısı & 0.6229 & 81.5230 & 0.2482 & 31.4571 \\
\hline Bitkide toplam verim & 0.0143 & 1.8695 & 0.4056 & 51.4017 \\
\hline Hasat İndeksi & 0.0025 & 0.3275 & -0.0063 & 0.7953 \\
\hline 1000 tane ağırlığı & -0.0037 & 0.4902 & -0.0025 & 0.3214 \\
\hline Bitkide tane sayısı & 0.7251 & 85.2062 & 0.3180 & 42.6030 \\
\hline Bitki boyu & 0.0095 & 1.1118 & -0.0130 & 1.7364 \\
\hline İlk bakla yüksekliği & -0.0287 & 3.3775 & 0.0334 & 4.4726 \\
\hline Bitkide bakla sayısı & -0.0694 & 8.1553 & 0.0329 & 4.4089 \\
\hline Bitkide toplam verim & 0.0117 & 1.3696 & 0.3309 & 44.3284 \\
\hline Bitkide hasat indeksi & 0.0033 & 0.3823 & -0.0176 & 2.3518 \\
\hline 1000 tane ağırlığı & -0.0034 & 0.3972 & -0.0007 & 0.0990 \\
\hline Bitkide toplam verim & 0.0327 & 8.4397 & 0.5807 & 68.9731 \\
\hline Bitki boyu & 0.0312 & 8.0668 & 0.0218 & 2.5857 \\
\hline İlk bakla yüksekliği & -0.0273 & 7.0429 & 0.0173 & 2.0583 \\
\hline Bitkide bakla sayısı & -0.0353 & 9.1183 & 0.0295 & 3.4985 \\
\hline Bitkide tane sayısı & 0.2586 & 66.7744 & 0.1812 & 21.5267 \\
\hline Bitkide hasat indeksi & -0.0011 & 0.2755 & -0.0095 & 1.1303 \\
\hline 1000 tane ağırlığı & 0.0011 & 0.2824 & 0.0019 & 0.2274 \\
\hline Bitkide hasat indeksi & 0.0336 & 25.9235 & 0.2449 & 74.0437 \\
\hline Bitki boyu & 0.0011 & 0.8570 & 0.0079 & 2.4015 \\
\hline İlk bakla yüksekliği & -0.0153 & 11.8006 & -0.0122 & 3.6766 \\
\hline Bitkide bakla sayısı & -0.0060 & 4.6630 & -0.0011 & 0.3266 \\
\hline Bitkide tane sayısı & 0.0701 & 54.0642 & -0.0228 & 6.8909 \\
\hline Bitkide toplam verim & -0.0010 & 0.7990 & -0.0226 & 6.8201 \\
\hline 1000 tane ağırlığı & 0.0025 & 1.9226 & 0.0193 & 5.8407 \\
\hline 1000 tane ağırlığı & 0.0301 & 15.6195 & 0.0503 & 8.1173 \\
\hline Bitki boyu & -0.0365 & 18.9108 & -0.0184 & 8.1173 \\
\hline İlk bakla yüksekliği & 0.0310 & 16.0449 & 0.0349 & 15.3866 \\
\hline Bitkide bakla sayısı & 0.0100 & 5.2053 & -0.0021 & 0.9388 \\
\hline Bitkide tane sayısı & -0.0813 & 42.1615 & -0.0047 & 2.0636 \\
\hline Bitkide toplam verim & 0.0012 & 0.6149 & 0.0221 & 9.7604 \\
\hline Bitkide hasat indeksi & 0.0028 & 1.4430 & 0.0941 & 41.5465 \\
\hline
\end{tabular}

verimi üzerinde en yüksek doğrudan ve olumlu etkiye sahip olduklarını, kabuli tip kışlık nohut geliştirirken de bu iki özelliğin dikkate alınmasının uygun olacağını ifade etmişlerdir.
Kışlık ekimde bitkide tane sayısı karakteri ön plana çıkarken yazlık ekim de bitkide hasat indeksi ve bitkide toplam verim karakterleri ön plana çıkmıştır. Yücel ve ark. (2006) nohutta 
tane sayısıyla, dolu bakla sayısının bitkide tane verimi üzerinde en yüksek doğrudan ve olumlu etkiye sahip olduklarını, kabuli tip kışlık nohut geliştirirken de bu iki özelliğin dikkate alınmasının uygun olacağını ifade etmişlerdir. Bu bildirişlerde bizim bulgularımızı destekler niteliktedir.

\section{Sonuç}

Sonuç olarak ifade etmek gerekirse; nohutta değişen ekim zamanına bağlı olarak bitkide tane verimi üzerin etkili olan bitkisel karakterlerin de değiştiği, nohutta yeni çeşitler geliştirilecek ıslah çalışmalarında istenen tip de bitki seçilirken değişen çevresel şartların dikkate alınması ve farklı çevrelerde üstün verim gösterebilecek bitkisel karakterlerin belirleneceği çalışmaların yapılması, kışlık ekime uygun olacak nohut genotiplerinin geliştirileceği çalışmalarda bitkide tane sayısı özelliği, yazlık ekimde de bitkide hasat indeksi ve bitkide toplam verim karakterlerinin öncelikle dikkate alınması ancak yüksek ve olumlu dolaylı etkileri nedeniyle de bitkide bakla sayısı özelliği de göz önünde tutulması gerekliliği kanaatleri oluşmuştur.

\section{Kaynaklar}

Akçin A., 1988. Yemeklik Dane Baklagiller. Selçuk Üni. Ziraat Fak. Yay. No: 8, Konya

Akdağ C., 2001. Tokat'ta yüksek verim sağlayacak nohut çeşitleri ile ekim zamanlarının belirlenmesi. GOP Üniv. Ziraat Fak. Yay. No: 59, Araş. Serisi No: 19, Tokat

Akdağ C. ve Şehirali S., 1992. Nohut (Cicer arietinum L.)'da özellikler arası ilişkiler ve path katsayısı analizi üzerinde bir araştırma. Doğa, 16: 763772

Al-Rifaee M.K., Yassin A.A., Haddad N. and AlTawaha A.M., 2007. Evaluation of chickpea breeding lines by examining their responses to sowing date at two Mediterranean climatic locations. American-Eurasian Journal of Sustainable Agriculture, 1(1): 19-24

Çiftçi V., Toğay N., Toğay Y. and Doğan Y., 2004. determining relationships among yield and some yield components using path coefficient analysis in chikpea (Cicer arietinum L.). Asian Journal of Plant Sciences, 3(57): 632-635

Düzdemir O. ve Akdağ C., 2007. Bazı nohut (Cicer arietinum L.) çeşitlerinde genotip $\mathrm{x}$ çevre interaksiyonlarının belirlenmesi üzerine bir araştırma. GOÜ Ziraat Fak. Dergiาsi, 24(1): 27-34
Düzdemir O., Yanar Y., Yazıcı S. ve Akdağ C., 2009 Nohut (Cicer arietinum L.)'da bitkide tane verimi ile bazı bitkisel özellikler arasındaki ilişkilerin belirlenmesi, Tarım Bilimleri Araştırma Dergisi, 1(2): 55-62

Erman M., Çiftçi V. and Geçit H.H., 1997. A research on relations among the characters and path coeffcient analysis in chikpea (Cicer arietinum L.). Agricultural Faculty, Ankara University, J. Agric. Sci., 3: 43-46

Eser D., Geçit H.H., Emeklier Y. and Kavuncu O., 1989. Increasing and valuating of chikpea gene material. Turkısh Journal of Agriculture Forestry, 13: 246-254

Güler M., Adak M.S. and Ulukan H., 2001. Determining relationships among yield and some yield components using path coefficient analysis in chickpea (Cicer arietinum L.). European Journal of Agronomy, 14: 161-166

Iliadis C., 2001. Evaluation of six chickpea varieties for seed yield under autumn and spring sowing. The Journal of Agricultural Science, 137: 439-444

Özdemir S. and Engin M., 1994. Effect of $\mathrm{NaCl}$ concentration on germination and seedling growth of chickpea (Cicer arietinum L.). Tr. J. of Agriculture and Forestry, 18: 323-328

Özdemir S. and Karadavut U., 2003. Comparison of the performance of autumn and spring sowing of chickpeas in a temperate region. Turk $\mathrm{J}$. Agric. For., 27: 345-352

Sepetoğlu H., 1994. Yemeklik Dane Baklagiller. Ege Üni. Ziraat Fak. Yay. No: 24, İzmir

Sağır A., Biçer B.T. and Şakar D., 2004. Correlations among characters and ascochyta blight disease severities in chikpea breeding lines. Plant Pathology Journal, 3(1): 40-43

Singh K.B. and Bejıga G., 1990. Analysis of stability for some characters in kabuli chickpea. Euphytica, 49: 223-227

Singh K.B., 1997. Chickpea (Cicer arietinum L.). Field Crops Res. 53: 161-170

Singh K.B., Malhotra R.S., Saxena M.C. and Bejiga G., 1997. Superiority of winter sowing over traditional spring sowing of chickpea in the Mediterranean Region. Agron. J., 89: 112-118

Smithson J.B., Thompson J.A. and Summerfield R.J., 1985. The grain legumes. Chickpea (Cicer arietinum L.), Chapter: 8, pages: 312-391. Collins Professional and Technical Books

Tawaha A.R.M., Turk M.A. and Lee K.D., 2005. Adaptation of chickpea to cultural practices in a Mediterranean type environment. Res. J. Agric. Bio. Sci., 1: 152-157 
Düzdemir "Kışlık ve Yazlık Yetiştirilen Nohut (Cicer arietinum L.)'ta Ekim Zamanlarına Göre Bitkide Tane Verimi ile Bazı Bitkisel Özellikler Arasındaki Illişkilerin İncelenmesi"

Toker C. ve Çağırgan İ., 1996. Kışıı nohut (Cicer arietinum L.) ekimi ve ıslah yaklaşımları. Akdeniz Üni., Ziraat Fakültesi Dergisi, 9: 123137

TUiK 2015. www.tuik.gov.tr/PrelstatistikTablo. do?istab_id=56
Yücel O.D., Anlarsal A.E. and Yücel C., 2006. genetic variability, correlation and path analysis of yield, and yield components in chickpea (Cicer arietinum L.). Turkish Journal of Agriculture and Forestry, 30: 183-188

Yurtsever N., 1984. Deneysel İstatistik Metotları. TOKB. Köy Hiz. Gn. Md. No: 121, no:56 623 s, Ankara 